\title{
SOCIAL MEDIA MARKETING IN \\ COMPARISON WITH OTHER FORMS OF MARKETING IN THE SLOVAK BANKING SECTOR
}

\section{MARKETING NA DRUŠTVENIM MEDIJIMA U USPOREDBI S DRUGIM OBLICIMA MARKETINGA U SLOVAČKOM BANKARSKOM SEKTORU}

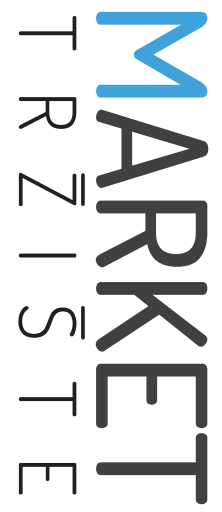

\section{Martin Vejačka}

Faculty of Economics, Technical University of Košice, Nemcovej 32, 04001, Košice, SLOVAKIA, martin.vejacka@tuke.sk

\begin{abstract}
Purpose - Social media have become an important marketing tool in recent years, used for marketing purposes by Slovak banks besides other forms of communication. A comparison of social media marketing perception by banks' customers on the Slovak market with other forms of marketing, examined across age groups, will be the main aim of this paper.
\end{abstract}

Design/Methodology/Approach - This investigation was conducted using a questionnaire survey with self-assessment statements, rated on a five-point Likert scale to compare the perception of items influencing the decision whether to use a bank or its services. The results were presented using descriptive statistics, z-scores, top two box scores, the Kruskal-Wallis test, the Mann-Whitney test, and Pearson's correlation.

Findings and implications - A relatively low level of perceived influence of social media marketing compared to those in other forms of marketing was detected in the process of decision-making about the adoption of a bank and its services. Higher levels of perceived influence were detected mainly in younger groups of respondents.

Limitations - These results give only a basic overview of the customer perception of social media marketing in

\section{Sažetak}

Svrha - Društveni su mediji postali važan marketinški alat tijekom posljednjih godina. Slovačke ga banke također koriste u marketinške svrhe uz druge oblike komunikacije. Glavni je cilj rada usporedba percepcija marketinga na društvenim medijima s percepcijama drugih oblika marketinga od strane korisnika bankarskih usluga različitih dobnih skupina na tržištu Slovačke.

Metodološki pristup - Istraživanje je provedeno anketiranjem uz korištenje upitnika sa samoprocjenjujućim izjavama, s Likertovom ljestvicom od pet stupnjeva, korištenom za usporedbu percepcija čimbenika koji utječu na odluku o korištenju banke ili njezinih usluga. Rezultati su prikazani korištenjem deskriptivne statistike, z-vrijednosti, Kruskal-Wallisovim testom, Mann-Whitneyjevim testom i Pearsonovim koeficijentom korelacije.

Rezultati i implikacije - Otkrivena je relativno niska razina percipiranog utjecaja marketinga na društvenim medijima kao i drugih oblika marketinga u procesu odlučivanja o prihvaćanju banke i njezinih usluga. Viša razina percipiranog utjecaja otkrivena je uglavnom kod mlađih grupa ispitanika.

Ograničenja - Rezultati daju samo osnovni pregled percepcija korisnika o marketingu na društvenim medijima 
comparison with other forms used in the Slovak banking market. Deeper relations between various forms of marketing and their perceptions might be investigated. The results have low explanatory power because of the limited sample size.

Originality - The investigation of the clients' social media marketing perception and its comparison with the perception of other marketing forms used in the Slovak banking market, including age-related differences, has not been conducted before.

Keywords - social media, social media marketing, banking, perception, comparison u usporedbi s percepcijama drugih oblika marketinga na slovačkom bankarskom tržištu. Potrebno je istražiti dublje odnose između različitih oblika marketinga i njihove percepcije. Rezultati se ne mogu poopćavati uslijed ograničene veličine uzorka.

Doprinos - Istraživanje percepcija korisnika o marketingu na društvenim medijima i njihova usporedba s percepcijama drugih korištenih oblika marketinga, uključujući razlike među dobnim skupinama, nije se do sada provodilo na slovačkom bankarskom tržištu.

Ključne riječi - društveni mediji, marketing na društvenim medijima, bankarstvo, percepcije, usporedba 


\section{INTRODUCTION}

Information technologies have had a significant impact on the field of services provision by rapidly changing the ways of delivering services. The financial services sector is continually evolving (Rajaobelina, Brun \& Toufaily, 2013), and this technological change has had one of the greatest impacts on the industry (Murray, Durkin, Worthington \& Clark, 2014). More and more investigators are studying both the influence of these technological changes on customer behavior and customers' acceptance of them (Rainer \& Puschmann, 2012; Durkin, Mulholland \& McCartan, 2015).

The emergence of social media in recent years has allowed marketers to reach potential customers in new, unique ways and forms. Social media allow the exchange of various types of content in digital networks. Users create profiles on a social media site or in an application designed and maintained by the social media organization. User profiles can connect with other users' profiles and create networks (Obar \& Wildman, 2015). Kietzmann, Hermkens, McCarthy and Silvestre (2011) explain that social media depend on mobile and web-based technologies to create highly interactive platforms through which individuals and communities share, co-create, discuss, and modify user-generated content.

Social media might add value to consumers beyond existing e-commerce activities (Culnan, McHugh \& Zubillaga, 2010). Social media can complement other channels of communication with an organization and can help manage service quality for consumers (Laroche, Habibi, Richard \& Sankaranarayanan, 2012). The collective discussion of retail bank experiences has intensified as more customers discuss their bank experiences in online communities, often organized around shared interests (Medberg \& Heinonen, 2014). Retail bank discussions can be found in most large online communities because almost everybody needs bank services. Social media offer major possibilities for companies and researchers to gain insight into customers' opinions and experiences (Helkkula \& Kelleher, 2010). Moreover, using social media allows organizations to influence conversations about their brand, also influencing consumer perceptions about the brand's credibility and reputation (Farshid, Plangger \& Nel, 2011) and building brand communities (Scarpi, 2010).

Thanks to the network of users, a company or a product can get attention in given social media free of charge. Social media might support brand awareness, which can lead to higher sales and market shares. In addition, user interaction with a brand might be more immediate when mediated by social media (Ferencová, Jeleňová \& Kakalejčík, 2015). Social media in general are considered powerful marketing tools. Most companies feel obliged to be presented on all major social media and to communicate their brands and products there (Bačík \& Fedorko, 2014). In recent years, the use of social media for marketing purposes has also become a common element of the marketing activities of a majority of retail banks.

A closer examination of the role of digital or social media technology in retail bank relationships is often conducted at the level of practitioners and industry specialists rather than academics (Alter, 2014; Durkin, McGowan \& Murray, 2014; Durkin et al., 2015). Banks in developed markets have been using social media for marketing purposes for a few years already, and banks in Slovakia have slowly started to follow this trend (Bačík, Fedorko, Kakalejčík \& Pudło, 2015). Durkin and others (2014) reported that retail banking has been slow to adopt new technologies and thus investigated the social and technical aspects of social media in the retail banking context. Many banks employ social media as a way of soliciting customer comment and feedback, as well as complaint handling. Social media presents a new way of accomplishing the task of gaining customer feedback and comments, while the remote nature of the Facebook social media platform will potentially alter the role of the staff previously involved in this process (Durkin et al., 2014).

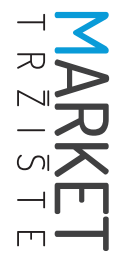




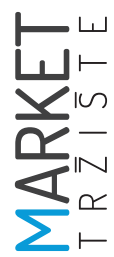

Chikandiwa, Contogiannis and Jembere (2013) investigated the adoption of social media marketing by banks in South Africa, detecting an increasing role of social media in customer reactive service and advertising.

On the other hand, the investigation of the customer's point of view is also an important part of the issue. Medberg and Heinonen (2014) indicated the factors of value formation in retail banking by exploration of social media discussions in online communities of retail banking customers. Mitic and Kapoulas (2012) detected low customer demand for social media interaction with banks, suggesting that social media might be more appropriate for smaller or younger banks seeking innovative ways to capture market share. Dootson, Beatson and Drennan (2016) investigated the consumer's perspective in social media adoption by financial institutions between two moments in time by exploring the role of value in consumer adoption and usage of social media. Their findings suggest that consumers will use social media if the sector creates and clearly articulates consumer value from using social media.

Various approaches have been used to investigate the role of social media in retail banking. However, the examination of the adoption of a bank or its services by a customer's self-reported influence by social media marketing when compared with other marketing forms has not yet been attempted. This topic will be the main object of investigation of our paper.

\section{LITERATURE REVIEW}

Typical examples of social media are Facebook, YouTube, Linkedln, and Twitter. Companies can time, social media are now an essential platform for promotion and public communication.

\subsection{Social media marketing in general}

Most companies, institutions, and non-profit organizations, including retail banks, are on Facebook or some other social media (Bačík et al., 2015). According to Kim and Bae (2008), companies have positive experience with social media marketing in general. Many studies have investigated specific social media marketing objectives (e.g. Bianchi \& Andrews, 2015; Bernoff \& Li, 2008; etc.), such as supporting brand awareness, decreasing marketing costs, increasing sales, and enhancing brand image by interaction with users on social media. Furthermore, companies might overview and analyze public conversations in social media to identify consumer sentiment towards their company (Schweidel \& Moe, 2014). In addition, companies often define rules for their employees about social media usage in cases regarding their work to avoid potential damage to the company's image (Rokka, Karlsson \& Tienari, 2014).

Hennig-Thurau and others (2010) investigated parts creating social media to expose its implications for companies. The effectiveness of social media marketing may also be affected by the role that consumers assign to companies in the social media. Companies might be viewed by their customers as unwanted elements in social media interaction (Schultz \& Peltier, 2013). On the other hand, other studies (e.g. Canhoto \& Clark, 2013; Ashley \& Tuten, 2015) have indicated that many customers desire the companies' participation in social media or even involve them in such interaction. In his study Stelzner (2012) detected that social media marketing increased customer traffic, generating more market exposure. In addition, it reduced the marketing expenses and brought new business partnerships. Zabin (2009) found out that social media marketing in most cases improves the return on marketing investment, increases the customer acquisition rate and the likelihood of 
recommendation of the firm's products or services by customers.

The customers' attitude towards social media marketing in general was investigated by Motwani, Shrimali and Agarwal (2014). They detected the positive customers' perception of social media marketing, indicating it to be more innovative, informative, and interactive. Vinerean, Cetina, Dumitrescu and Tichindelean (2013) investigated the effects of social media marketing on an online consumer and detected positive reactions to social media marketing mainly in the group of customers who have extensive experience with social networking sites.

\subsection{Social media marketing in retail banking}

In the retail banking sector, social media usage has its specifics. Banks are often considered to be conservative and dignified institutions, and their marketing communications reflect this status in most cases; however, electronic or Internet banks are often more progressive in many areas (Vejačka, 2015). The use of social media by retail banks gives them an opportunity to reach vast numbers of potential customers with good possibilities for gathering feedback and analyzing the data about their campaigns in the given social media. Their marketing might be more social media centric, as they often aim at the younger generation of users, who are especially present on social media. Grabner-Kräuter and Faullant (2008) confirmed that banks in general should build up their innovative reputation. Obtaining a positive word-of-mouth reputation even via social media (electronic word-of-mouth) will enhance positive perceptions among potential customers and improve the trustworthiness of the banks in question. Durkin and others (2014) noted that banks use Facebook (as one example of social media) primarily to monitor customer comments and complaints and to respond to them. Madche (2015) found that it is vital for the bank to be in the same space as its customers, which explains their extensive presence on social media channels. Social media might also have an educational influence on bank customers. For example, Deutsche Bank has a YouTube channel with videos that explain financial products and provide basic financial education (Madche, 2015). In South Africa, banks have successfully used YouTube to teach young people budgeting and savings skills (Chikandiwa et al., 2013).

However, the results of Mitic and Kapoulas (2012) indicate a low demand for social media interaction with banks by their customers; therefore, they suggest that social media communication and marketing should be used by progressive and innovative banks mainly among young customers, who more readily adopt new trends. Durkin and others (2015) highlighted the role of social media as a channel for acquiring customer feedback and resolving complaints, thus partially changing the ways of providing customer support. Similar results were acquired by Chikandiwa and others (2013) with the addition of the educational possibilities of social media in emerging markets. Rokka and others (2014) emphasized social media as a tool for enhancing corporate reputation. Many other studies investigate how social media can be used by financial institutions for managing relationships with customers (e.g. Murray et al., 2014), increasing the value of small banks (Durkin et al., 2014), managing brand image (Farshid et al., 2011) or increasing financial literacy (Chikandiwa et al., 2013).

Social media have become a permanent part of banks' marketing strategies (Greenberg, 2010), although, according to multiple studies (e.g. Lariviere et al., 2013; Dootson et al., 2016), consumers are much more likely to interact with family and friends on social media than with commercial brands. Therefore, it becomes increasingly important to understand how consumers perceive social media marketing in retail banking. Durkin and others (2015) detected that age was a significant determinant of the appropriateness of social media use by banks: generally, young consumers are accepting of their broader use of social media. Furthermore, social media should not displace the role of online banking. Medberg and Heinonen (2014) investigated so-

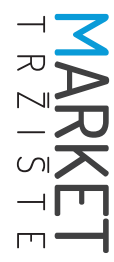




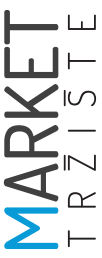

cial media discussions of customers and determined the factors creating value for retail banking customers. Dootson and others (2016) detected that customers must perceive the use of social media by banks as having value in order to adopt it. Banks should therefore create and communicate this value to them.

Thus, social media marketing in retail banking has been examined at an international level in recent years from multiple points of view, but in the Slovak retail banking market such an investigation is missing.

\subsection{Social media marketing in retail banking in Slovakia}

In Slovakia, banks (following the example of those in developed countries) have begun to use social media for communication and marketing purposes. In general, online marketing usage in Slovakia has lagged behind the top countries. In Vejačka (2012), Facebook was measured as an example of social media and its advertising efficiency in the Slovak environment in general. The results showed increasing possibilities of Facebook use for marketing purposes in Slovakia and abroad. Since then, the use of social media marketing by Slovak companies has increased, and revenues from online advertising (including social media marketing) have grown significantly in recent years (Bačík \& Fedorko, 2014), with the exception of the crisis year of 2009.

The banks present on the Slovak market also use marketing via social media at an increasing rate. According to Bačík and others (2015), all retail banks in Slovakia use social media (Facebook, Twitter, Linkedln, Google+, etc.) for communication with their clients and for advertising purposes at the same time. All retail banks on the Slovak market are officially present on at least one of the most popular social networks. Furthermore, some of them also use blogs as part of their marketing communication and public relations.

Therefore, the role of social media in retail banking has been investigated from various points of view. However, the adoption of retail banking services by a customer's self-reported influence by social media advertising and marketing in comparison with other marketing forms in the Slovak banking sector has not been conducted yet. The influence of social media marketing by Slovak banks on the adoption of their services might be very interesting for marketers at these banks when creating new marketing strategies. So it will be the main aim of our examination. An investigation of the conditions and specifics of the Slovak retail banking sector will be also conducted for reasons of convenience, familiarity of the market to the author, and the lack of investigation in this area in the Slovak retail banking market.

\section{RESEARCH METHODOLOGY AND RESULTS}

Dootson and others (2016) used self-administered surveys run at two points in time in order to gather data enabling a comparison between the two time-points. Ferencová and others (2015) used their own questionnaire survey to gather data for an inter-gender comparison of social media use in product information searching. A similar method of data collection was conducted in our research to gather data suitable for our intended analysis. Over 1,100 potential respondents from Slovakia were sent electronic or paper forms of a questionnaire during the period from January 2016 to April 2016. In this drive, 387 usable answered questionnaires were attained. The respondents were sampled using a disproportionate stratified random sampling method with strata equal to the age subgroups. The subgroups included in the sample with higher sampling fractions were the groups encompassing 16- to 25-year-olds and 26- to 35 -year-olds. The reason for the higher inclusion of these age groups is the higher probability of more relevant results, since these subgroups were found to use social media more often. The age group encompassing 0 to 15 years of age was not included because of its minimal rele- 
vance to the research. A decreased fraction of the sample was used for the age group including 56-year-olds and older, as they indicated social media use very rarely. Other age groups (36-45 years old and 46-55 years old) were represented in the fractions corresponding to their proportion in the Slovak population (Statistical Office of the Slovak Republic, 2016).

The survey questionnaire investigated each respondent's basic demographic information, use of bank services, and social media. In the second part of the survey, the respondents using bank services were asked to express their agreement with 11 general statements regarding the influence of bank marketing on them. Self-reported perception of the influence of particular factors is a frequent method of technology acceptance investigations (e.g. Davis, Bagozzi \& Warshaw, 1989; Pikkarainen, Pikkarainen, Karjaluoto \& Pahnila, 2004). Studies of technology acceptance often use the Technology Acceptance Model (TAM) to develop perceived influence constructs and then interpret influence using factor analysis. Social media marketing is a relatively new form of marketing using the technology of social media. The acceptance technology of social media in general is not the aim of our investigation. Therefore, the TAM model is substituted here by our proposed statements and analyzed not by factor analysis but by means of other statistical methods.

The collected data was further statistically analyzed using descriptive statistics, z-scores, and the top two box scores as the legitimate basic methods for satisfaction comparisons (Anderson \& Mittal, 2000). In addition, a comparison of the perception of social media use by retail banks between age groups was conducted using the Kruskal-Wallis test for the detection of stochastic dominance in the whole sample and the Mann-Whitney pairwise test to analyze specific sample pairs for stochastic dominance (Spurrier, 2003). Moreover, the inter-correlations between agreement scores of the survey statements were used to compare their pairwise relationship (Porter \& Donthu, 2006).

\subsection{Survey results}

The first part of our questionnaire gathered demographic data of respondents. The sample of respondents contained 201 women and 186 men. According to the age, the respondents were divided into 5 ranges: 16 to 25 years (or Group 1), 26 to 35 years (Group 2), 36 to 45 years (Group 3), 46 to 55 years (Group 4), and 56 years and above (Group 5). Most of the respondents were in the ranges of 16 to 25 years (94 respondents, 24.29\%) and 26 to 35 years (84 respondents, 21.71\%); in these age groups the highest rates of social media use was anticipated and, therefore, a greater probability of gathering valuable data on social media marketing. The other age groups, however, still constituted a significant part of the sample: 36 to 45 years (75 respondents, 19.38\%), 46 to 55 years (79 respondents, 20.41\%), and 56 and more (55 respondents, 14.21\%). Table 1 shows all the demographic data of our sample.

Furthermore, data on the use of bank services and social media was gathered. Only 13 respondents (3.36\%) reported that they do not use banking services at all. Two thirds of respondents $(259,66.93 \%)$ uses the banking services of only one bank. Over 15 percent (59 respondents) cite the use of banking services of two banks at present, and 14.47 percent (56 respondents) stated they used the services of three banks. None of them claimed they used more than three banks' services. These results show quite a high diversification of the provision of banking services on the Slovak banking market. Clients quite often have a bank account in one bank and a savings account or credit card issued by another bank.

Virtually all the users of banking services (374 respondents) had a current account, and more than 80 percent also had a debit or credit card. Over 49 percent of our respondents had account overdraft, and over 9 percent had taken out consumer credit loans. A mortgage of any type had been provided to 29.41 percent of the bank customers surveyed. More than 40 percent of bank clients used a savings account of any type. 
TABLE 1: Demographic data of survey sample

\begin{tabular}{|c|c|c|c|}
\hline \multicolumn{2}{|l|}{ Item } & \multirow{2}{*}{\begin{tabular}{|c|} 
Frequency \\
186 \\
\end{tabular}} & \multirow{2}{*}{$\begin{array}{c}\text { Percentage } \\
48.06 \%\end{array}$} \\
\hline Gender & Male & & \\
\hline vericer & Female & 201 & $51.94 \%$ \\
\hline \multirow{5}{*}{ Age } & 16 to 25 years (Group 1) & 94 & $24.29 \%$ \\
\hline & 26 to 35 years (Group 2) & 84 & $21.71 \%$ \\
\hline & 36 to 45 years (Group 3) & 75 & $19.38 \%$ \\
\hline & 46 to 55 years (Group 4) & 79 & $20.41 \%$ \\
\hline & 56 years and older (Group 5) & 55 & $14.21 \%$ \\
\hline \multirow{4}{*}{$\begin{array}{l}\text { Population, place } \\
\text { of residence }\end{array}$} & Over 100000 citizens & 230 & $59.43 \%$ \\
\hline & Between 10000 and 100000 citizens & 43 & $11.11 \%$ \\
\hline & Between 5000 and 10000 citizens & 53 & $13.70 \%$ \\
\hline & Less than 5000 citizens & 61 & $15.76 \%$ \\
\hline \multirow{5}{*}{ Net income } & $€ 0$ to $€ 300$ & 83 & $21.45 \%$ \\
\hline & $€ 301$ to $€ 600$ & 92 & $23.77 \%$ \\
\hline & $€ 601$ to $€ 900$ & 101 & $26.10 \%$ \\
\hline & $€ 901$ to $€ 1200$ & 56 & $14.47 \%$ \\
\hline & $€ 1201$ and more & 55 & $14.21 \%$ \\
\hline \multirow{8}{*}{ Occupation } & Students & 83 & $21.45 \%$ \\
\hline & Employees & 212 & $54.78 \%$ \\
\hline & Entrepreneurs & 23 & $5.94 \%$ \\
\hline & Pensioners & 39 & $10.08 \%$ \\
\hline & Unemployed & 7 & $1.81 \%$ \\
\hline & Students and entrepreneurs & 3 & $0.78 \%$ \\
\hline & Students and employees & 13 & $3.36 \%$ \\
\hline & Employees and entrepreneurs & 7 & $1.81 \%$ \\
\hline
\end{tabular}

Source: own processing of gathered survey data

Almost 75.94 percent of bank clients in the survey stated they used electronic banking. This result is slightly below the global results of Ernst \& Young (2014), which showed the global average at a level of 81 percent. Most of the bank clients within the sample (75.40\%) used Internet banking, followed by electronic payments services using payment cards (58.29\%), and mobile banking use (47.59\%).

Over 12 percent of the respondents indicated that they do not use any social media; these were mainly in the higher age groups of 46 to 55 years and 56 years and older. Facebook is used by almost two thirds (65.89\%) and Youtube by more than half of all the respondents (53.75\%). Linkedln is used by 26.36 percent, Google+ by 16.02 percent, and Instagram by 8.27 percent of the respondents. Twitter use was indicated only in 7 answers (1.81\%). Pinterest, Goodreads, and Myspace were indicated only once each. No additional social media were detected in the survey.

Most of the respondents (45.74\%) used social media less than one hour per day. Between one and two hours were spent each day on social media by 112 respondents (28.94\%). The use of 
social media for 3 to 4 hours per day was indicated by 8.79 percent of the correspondents and more than 4 hours was claimed by $13.18 \%$ of respondents. Those surveyed also indicated that they use other forms of social media: $25.32 \%$ cited the use of wikis while $34.63 \%$ said they used blogs.

The results show quite wide use of social media by Slovak users. This fact presents the potential for banks on the Slovak banking market to communicate and advertise via social media, which most of them actually take advantage of. In next part of the survey, the self-perceived influence of social media marketing of banks on Slovak users, when compared to other forms of marketing, was investigated.

\subsection{Comparison of marketing form perception by bank users}

Additionally, the influence of multiple factors in the decision of respondents on whether to use a bank and its products were investigated by a set of 11 self-assessment statements. The respondents reported their self-perceived influence by various forms of marketing communication.

The emphasis was placed on social media marketing of banks (abbreviation used: SMMB) in comparison with the other forms of bank marketing: namely, classic web marketing such as banners (WMB), television or radio marketing (TVRM), print media marketing (PMM), and marketing using billboards (BBM). The first five statements were aimed at examining the self-reported perception of these forms of marketing used by the retail banks in Slovakia by our respondents. The influence of these forms on a bank or service adoption decision was investigated and further complemented with three other basic factors: the price of banking services (PRC), satisfaction of user's requirements (RQS) by the given banking service, and the recommendation of a bank or its service by a family member or a friend (RCF), commonly known as word-of-mouth reputation. These factors were included with the aim of allowing the comparison of multiple marketing mix elements. The last section contained three statements about the user's perception of social media marketing in general (SMMG), the bank's communication in social media not in the form of advertisements (BCSM), and the advertising of their bank in social media (ACSM). The perception of social media marketing in general was included to investigate its self-reported perception by our respondents in comparison with social media marketing specially in the retail banking sector. The other two statements (BCSM and ACSM) were included to allow the comparison of the perception of the specific aspects of social media marketing in retail banking with the perception of social media marketing of banks as whole.

A five-point Likert scale was used to measure the answer options, which ranged from "strongly disagree" to "strongly agree". Only the answers of bank clients among the respondents were considered in this part, so the number of respondents analyzed was only 374. Table 2 provides an overview of the statistical measures of answers gathered for the comparison of customers' perceptions of social media marketing of their banks with other marketing forms and factors.

The methodology for measuring agreement with provided statements was similar to that used by Nielsen and Levy (1994). In the first part, the 8 statements investigated whether customers' decision to use a bank and its products or services was affected by a particular form of marketing or by other basic factors. The second part consisted of 3 statements about customers noticing the bank's communication via social media, the advertising of their bank (or banks) via social media, and about whether they noticed marketing via social media in general. 
TABLE 2: Statistical measures of the survey data on customers' perception

\begin{tabular}{|c|c|c|c|c|c|c|c|}
\hline \multicolumn{2}{|l|}{ Statement } & \multirow{2}{*}{\begin{tabular}{|c|} 
Mean \\
1.72 \\
\end{tabular}} & \multirow{2}{*}{\begin{tabular}{|c|}
$\begin{array}{c}\text { Standard } \\
\text { deviation }\end{array}$ \\
0.852500
\end{tabular}} & \multirow{2}{*}{$\begin{array}{l}\text { Z-score } \\
-2.672228\end{array}$} & \multirow{2}{*}{\begin{tabular}{|c|}
$\begin{array}{c}\text { Percentile } \\
\text { rank }\end{array}$ \\
0.376735
\end{tabular}} & \multirow{2}{*}{\begin{tabular}{|c|}
$\begin{array}{c}\text { Coefficient } \\
\text { of Variation }\end{array}$ \\
0.495086 \\
\end{tabular}} & \multirow{2}{*}{$\begin{array}{c}\begin{array}{c}\text { Top two } \\
\text { box }\end{array} \\
0.040107\end{array}$} \\
\hline \multirow{8}{*}{$\begin{array}{l}\text { My decision } \\
\text { on using a } \\
\text { bank and its } \\
\text { products or } \\
\text { services is } \\
\text { affected by: }\end{array}$} & $\begin{array}{l}\text { Social media } \\
\text { marketing of banks } \\
\text { (SMMB) }\end{array}$ & & & & & & \\
\hline & $\begin{array}{l}\text { Web marketing of } \\
\text { banks (excluding } \\
\text { social media) (WMB) }\end{array}$ & 1.82 & 0.869917 & -2.511149 & 0.394015 & 0.479159 & 0.050802 \\
\hline & $\begin{array}{l}\text { TV or radio marketing } \\
\text { of banks (TVRM) }\end{array}$ & 2.66 & 0.660054 & -2.037591 & 2.079557 & 0.248600 & 0.066845 \\
\hline & $\begin{array}{l}\text { Print media } \\
\text { marketing of banks } \\
\text { (PMM) }\end{array}$ & 1.86 & 0.732624 & -2.926993 & 0.171118 & 0.394815 & 0.016043 \\
\hline & $\begin{array}{l}\text { Bank billboards } \\
\text { (BBM) }\end{array}$ & 1.74 & 0.728291 & -3.102273 & 0.096016 & 0.418404 & 0.021390 \\
\hline & \begin{tabular}{|l} 
Price of services \\
(PRC)
\end{tabular} & 3.83 & 0.906319 & -0.185861 & 42.627702 & 0.236541 & 0.756684 \\
\hline & $\begin{array}{l}\text { Requirements } \\
\text { satisfaction (RQS) }\end{array}$ & 4.03 & 0.954364 & 0.028017 & 51.117544 & 0.237007 & 0.681818 \\
\hline & $\begin{array}{l}\text { Recommendation } \\
\text { by family or friends } \\
\text { (RCF) }\end{array}$ & 3.83 & 0.863914 & -0.194984 & 42.270288 & 0.225474 & 0.737968 \\
\hline \multirow{3}{*}{ I do notice: } & $\begin{array}{l}\text { Bank's } \\
\text { communication via } \\
\text { social media (BCSM) }\end{array}$ & 1.71 & 0.961473 & -2.380482 & 0.864500 & 0.561861 & 0.056150 \\
\hline & $\begin{array}{l}\text { Advertising of my } \\
\text { bank via social } \\
\text { media (ABSM) }\end{array}$ & 2.07 & 1.211986 & -1.588412 & 5.609654 & 0.584127 & 0.184492 \\
\hline & \begin{tabular}{|l} 
Social media \\
marketing in \\
general (SMMG)
\end{tabular} & 2.14 & 1.010362 & -1.841877 & 3.274665 & 0.472344 & 0.090909 \\
\hline
\end{tabular}

Source: own processing of gathered survey data

The clearest overview shows us the high percentile rank and the top two box scoring (the agree percentage representing the proportion of agree and strongly agree answers). All investigated forms of marketing scored relatively low in this measurement. This result suggests that bank clients in Slovakia do not ascribe a high influence of these marketing forms on their decisions to use a particular bank or its services. The lowest agreement percentage was affected by print media marketing (1.6\%, 0.17 percentile rank), followed by banks' billboards (2.1\%, 0.10 percentile). Social media marketing of banks scored only a $4.0 \%$ agreement rate, and 0.38 percentile rank and was slightly exceeded by web marketing (5.1\%, 0.39 percentile) and TV or radio marketing (6.7\%, 2.08 percentile). 
FIGURE 1: Percentages of the self-assessment responses of Slovak bank customers on statements provided

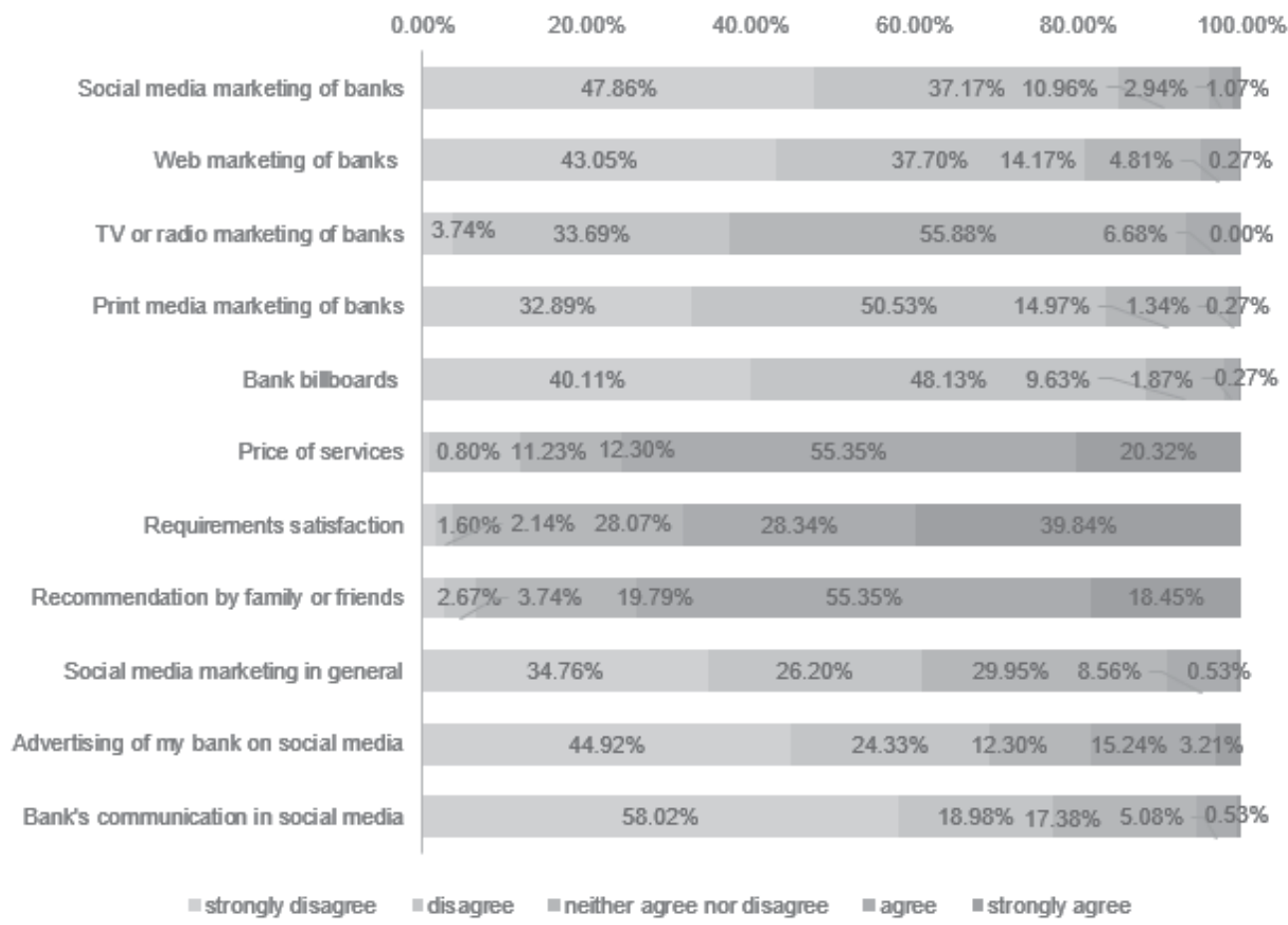

Source: own processing of gathered survey data (Likert 5-point scale from strongly disagree to strongly agree)

Figure 1 shows the percentages of all responses of bank customers participating in the survey and gives a good overview of the results. According to their self-assessment, the respondents are mostly influenced by the factors of how a bank or a banking service satisfies their requirements from it (51.12 percentile rank, $68.18 \%$ agreement rate), followed by the influence of the price of the banking service (42.63 percentile, $75.67 \%$ agreement rate), and that of a word-of-mouth recommendation by a friend or a family member (42.27 percentile, $73.80 \%$ agreement rate).

This suggests that our respondents do not perceive any of the aforementioned marketing forms as important for their decision to use a bank or its products, but rather the factors of price, recommendations, and the satisfaction of their requirements. Only $9.1 \%$ of the respondents stated that they notice social media marketing in general (not only marketing by banks), which is relatively higher than in the case of banks' social media marketing. However, 18.4\% of the respondents claimed they noticed the advertising of banks via social media. The inconsistence of these two results suggests that several respondents do not perceive advertisements in social media as being a part of social media marketing. Furthermore, only 5.6\% of the respondents claimed that they noticed communication of their bank (or banks) via social media, which corresponds with the other lower results of the social media marketing perception.

These results suggest that the level of influence of social media marketing on the decision of whether to use a bank and its products is similar to that of other forms of marketing. The respondents often accredited more importance to factors such as the price, word-of-mouth recommendation, and requirements satisfaction. They also did not notice social media marketing of banks at a high rate. The reason for this finding 
might lie in the fact that people do not use social media extensively in the process of deciding whether to use a bank or banking service. However, retail banks in Slovakia still might use social media marketing as an important part of a range of marketing tools, because it is perceived by the responding users of banking services at the similar level as the other investigated marketing channels.

For the purpose of detecting differences in the perception of the investigated items across age groups, a Kruskal-Wallis test was used with IBM SPSS Statistics software. It revealed statistically significant differences across age groups on all 11 investigated items (see Table 3). the significance of results must be below the level of 0.005 (significance level divided by the number of tests), or 0.001 respectively (Spurrier, 2003).

Multiple statistically significant differences in self-perceived influence between age groups of respondents were detected. Table 5 shows mean responses of the respondents divided into our age groups to allow a comparison of means across age groups. It allows easy comparison of self-perceived influence across a whole range of ages. The interesting and expected result is a very low perception of social media marketing (both in general and in the retail banking sector) by the respondents in age groups of 46- to 55-years-old and 56 years and

TABLE 3: Detection of differences across age groups of self-perceived influence by proposed items

\begin{tabular}{|l|c|c|c|c|c|c|c|c|c|c|c|}
\hline & SMMB & WMB & TVRM & PMM & BBM & PRC & RQS & RCF & BCSM & ABSM & SMMG \\
\hline Chi-Square & 176.6 & 192.6 & 24.38 & 41.47 & 96.92 & 146.87 & 105.34 & 51.1 & 205.89 & 225.98 & 227.08 \\
\hline Significance & $.000^{* *}$ & $.000^{* *}$ & $.000^{* *}$ & $.000^{* *}$ & $.000^{* *}$ & $.000^{* *}$ & $.000^{* *}$ & $.000^{* *}$ & $.000^{* *}$ & $.000^{* *}$ & $.000^{* *}$ \\
\hline
\end{tabular}

Source: own processing of data gathered (significance: $p<.01 * *$ )

TABLE 4: Inter-age group differences in self-perceived influence by proposed items

\begin{tabular}{|c|c|c|c|c|c|c|c|c|c|c|c|}
\hline $\begin{array}{c}\text { Age } \\
\text { groups } \\
\text { compared }\end{array}$ & SMMB & WMB & TVRM & PMM & BBM & PRC & RQS & RCF & BCSM & ABSM & SMMG \\
\hline $1-2$ & $0^{* *}$ & .09 & $.004^{*}$ & .26 & .214 & $.002^{*}$ & $.002^{*}$ & .095 & .158 & $.002^{*}$ & .074 \\
\hline $1-3$ & $.005^{*}$ & .02 & .846 & .248 & $0^{* *}$ & .032 & .568 & .008 & $0^{* *}$ & $0^{* *}$ & .844 \\
\hline $1-4$ & $0^{* *}$ & $0^{* *}$ & $.001^{* *}$ & .903 & .099 & $0^{* *}$ & $0^{* *}$ & $0^{* *}$ & $0^{* *}$ & $0^{* *}$ & $0^{* *}$ \\
\hline $1-5$ & $0^{* *}$ & $0^{* *}$ & .638 & $0^{* *}$ & $.002^{*}$ & $0^{* *}$ & $0^{* *}$ & $0^{* *}$ & $0^{* *}$ & $0^{* *}$ & $0^{* *}$ \\
\hline $2-3$ & $0^{* *}$ & .771 & $0^{* *}$ & .805 & $0^{* *}$ & $0^{* *}$ & .006 & .398 & $0^{* *}$ & $0^{* *}$ & .038 \\
\hline $2-4$ & $0^{* *}$ & $0^{* *}$ & .397 & .029 & $0^{* *}$ & .395 & $0^{* *}$ & .118 & $0^{* *}$ & $0^{* *}$ & $0^{* *}$ \\
\hline $2-5$ & $0^{* *}$ & $0^{* *}$ & .058 & $0^{* *}$ & .024 & $0^{* *}$ & $0^{* *}$ & $0^{* *}$ & $0^{* *}$ & $0^{* *}$ & $0^{* *}$ \\
\hline $3-4$ & $0^{* *}$ & $0^{* *}$ & $0^{* *}$ & .184 & $0^{* *}$ & $0^{* *}$ & $0^{* *}$ & .404 & .933 & $0^{* *}$ & $0^{* *}$ \\
\hline $3-5$ & $0^{* *}$ & $0^{* *}$ & .864 & $0^{* *}$ & $0^{* *}$ & $0^{* *}$ & $0^{* *}$ & $0^{* *}$ & .032 & $0^{* *}$ & $0^{* *}$ \\
\hline $4-5$ & .538 & .251 & .021 & $0^{* *}$ & $0^{* *}$ & $0^{* *}$ & .237 & $0^{* *}$ & .025 & .017 & .017 \\
\hline
\end{tabular}

Source: own processing of data gathered (significance: $p<.05 *, p<.01{ }^{* *}$ )

Consequently, the Mann-Whitney test was used to detect the differences among age groups pairwise. Table 4 shows all the results of these tests. Considering the number of tests (10 to cover all age groups), older. This suggests that retail banks in Slovakia should aim their social media marketing at younger clients. These results correspond with the results of Belás and Kotásková (2013). 
TABLE 5: Age group means of self-perceived influence by proposed items

\begin{tabular}{|c|c|c|c|c|c|c|c|c|c|c|c|}
\hline $\begin{array}{c}\text { Age } \\
\text { groups }\end{array}$ & SMMB & WMB & TVRM & PMM & BBM & PRC & RQS & RCF & BCSM & ABSM & SMMG \\
\hline $\mathbf{1}$ Mean & 2.45 & 2.38 & 2.49 & 2.03 & 1.99 & 3.49 & 4.06 & 3.46 & 2.33 & 3.22 & 2.73 \\
SD & 1.087 & .959 & .881 & .859 & .923 & 1.088 & 1.209 & 1.056 & 1.07 & 1.031 & .963 \\
\hline $\mathbf{2}$ Mean & 1.71 & 2.12 & 2.80 & 1.84 & 1.75 & 3.98 & 4.64 & 3.76 & 2.49 & 2.71 & 2.51 \\
SD & .669 & .683 & .433 & .418 & .560 & .490 & .482 & 1.103 & .736 & 1.036 & .611 \\
\hline $\mathbf{3}$ Mean & 2.03 & 2.12 & 2.51 & 1.87 & 1.19 & 3.16 & 4.31 & 3.80 & 1.17 & 1.64 & 2.79 \\
SD & .328 & .434 & .503 & .875 & .512 & .959 & .753 & .717 & .601 & .895 & .741 \\
\hline $\mathbf{4}$ Mean & 1.06 & 1.06 & 2.85 & 1.97 & 2.08 & 4.04 & 3.43 & 3.95 & 1.13 & 1.15 & 1.14 \\
SD & .334 & .331 & .361 & .236 & .402 & .250 & .796 & .354 & .435 & .483 & .416 \\
\hline $\mathbf{5}$ Mean & 1.06 & 1.00 & 2.62 & 1.30 & 1.49 & 4.94 & 3.43 & 4.51 & 1.00 & 1.00 & 1.00 \\
SD & .247 & .000 & .945 & .587 & .505 & .247 & .617 & .505 & .000 & .000 & .000 \\
\hline
\end{tabular}

Source: own statistical processing of data

The relations between the perceptions of items in- The interesting result here is that a service price cluded in our survey are illustrated in Table 6 using inter-correlations (Pearson's correlation) of items. perception seems to be negatively correlated with the social media marketing of banks in the

TABLE 6: Inter-correlations of proposed items

\begin{tabular}{|c|c|c|c|c|c|c|c|c|c|c|c|c|}
\hline \multicolumn{2}{|c|}{ Proposed factors } & \multirow{3}{*}{$\begin{array}{c}\text { SMMB } \\
1\end{array}$} & \multirow{3}{*}{\begin{tabular}{|c} 
WMB \\
$851^{* *}$ \\
0 \\
\end{tabular}} & \multirow{2}{*}{\begin{tabular}{|c|} 
TVRM \\
.079
\end{tabular}} & \multirow{2}{*}{\begin{tabular}{|l|} 
PMM \\
$.302^{* *}$
\end{tabular}} & BBM & PRC & RQS & RCF & BCSM & ABSM & SMMG \\
\hline & P correlation & & & & & $.233^{* *}$ & $-.292^{* *}$ & $.144^{* *}$ & $-.142^{* *}$ & $.453^{* *}$ & $.525^{* *}$ & $.721^{* *}$ \\
\hline SIVIVIB & Sig. (2-tailed) & & & .128 & 0 & 0 & 0 & .005 & .006 & 0 & 0 & 0 \\
\hline & P correlation & & 1 & $.121^{*}$ & $.295^{* *}$ & $200^{* *}$ & $-.240^{* *}$ & $.383 * *$ & $-.244^{* *}$ & $.607^{* *}$ & $.576 * *$ & $.721^{* *}$ \\
\hline WVIVIB & Sig. (2-tailed) & & & .027 & 0 & 0 & 0 & 0 & 0 & 0 & 0 & 0 \\
\hline TT/RM & P correlation & & & 1 & $.422^{* *}$ & $.352^{* *}$ & .028 & -.079 & $.109^{*}$ & $.121^{*}$ & -.058 & $.169^{* *}$ \\
\hline IVRIVI & Sig. (2-tailed) & & & & 0 & 0 & .588 & .127 & .034 & .019 & .262 & .001 \\
\hline & P correlation & & & & 1 & $.404^{* *}$ & $-.518^{* *}$ & $-.243^{* *}$ & -.065 & $.266^{* *}$ & .087 & $.317^{* *}$ \\
\hline PIVIMI & Sig. (2-tailed) & & & & & 0 & 0 & 0 & .234 & 0 & .114 & 0 \\
\hline & P correlation & & & & & 1 & -.029 & $.121^{*}$ & $-.174^{* *}$ & $.373^{* *}$ & $.274^{* *}$ & .69 \\
\hline BBIVI & Sig. (2-tailed) & & & & & & .601 & .028 & .001 & 0 & 0 & .210 \\
\hline & P correlation & & & & & & 1 & $.182^{* *}$ & $.354^{* *}$ & $-.124^{*}$ & -.081 & $-.408^{* *}$ \\
\hline PRC & Sig. (2-tailed) & & & & & & & 0 & 0 & .017 & .117 & 0 \\
\hline & P correlation & & & & & & & 1 & $-.102^{*}$ & $.280^{* *}$ & $.313^{* *}$ & $.196^{* *}$ \\
\hline RQS & Sig. (2-tailed) & & & & & & & & .049 & 0 & 0 & 0 \\
\hline RCF & P correlation & & & & & & & & 1 & $-.110^{*}$ & -.057 & $-.130^{* *}$ \\
\hline & Sig. (2-tailed) & & & & & & & & & .033 & .271 & 0 \\
\hline & P correlation & & & & & & & & & 1 & $.764^{* *}$ & $.442^{* *}$ \\
\hline$B C S$ & Sig. (2-tailed) & & & & & & & & & & 0 & 0 \\
\hline ABSM & P correlation & & & & & & & & & & 1 & $.523^{* *}$ \\
\hline & Sig. (2-tailed) & & & & & & & & & & & 0 \\
\hline SMMG & $\begin{array}{l}\text { P correlation } \\
\text { Sig. (2-tailed) }\end{array}$ & & & & & & & & & & & 1 \\
\hline
\end{tabular}


surveyed sample of Slovak bank clients. Thus, price-sensitive respondents do not perceive social media marketing (and multiple other forms) very positively, which can also help the banks in Slovakia to aim their social media campaigns. The social media marketing of banks (SMMB) correlates mainly with the general social media marketing (SMMG) and the web marketing of banks (WMB). This suggests that respondents with a more positive attitude towards information technologies such as the web (e.g. digital natives) indicated more often that they were influenced by social media marketing.

\section{CONCLUSIONS}

The results suggest that our respondents do not strongly perceive the social media marketing of their banks. They also perceive social media marketing of banks as having a low level of influence of their decision whether to use a bank and its services or products. This perceived level of influence, however, was similar to those of the other forms of marketing communication. According to the respondents, word-of-mouth recommendations, prices of services, and the satisfaction of their requirements had greater influence on their decision-making process. This corresponds with the results of Grabner-Kräuter and Faullant (2008), who detected the impor- tance for banks of obtaining positive word-ofmouth reputation.

The respondents do not pay much attention to the social media marketing of their banks, but this level of attention is comparable with that of the other forms of marketing. The result of noticing social media marketing in general was slightly higher, which indicates that a comparison with other segments of an economy might show some differences in social media marketing effects. When considering our further results, this can imply that bank marketing managers should use social media marketing mainly for groups of younger clients (below 45 years of age), where higher self-reported influence was indicated by the respondents.

These results give a hint of the customer perception of social media marketing in a general comparison with the other forms of marketing in the Slovak banking market. The results cannot be entirely generalized as they have low explanatory power because of the size of the sample, reflecting the resources available for the study. Furthermore, deeper relations between various forms of marketing according to their perceptions among bank clients (or using different methodology) might be investigated in future. However, a more in-depth investigation of social media marketing in the Slovak retail banking sector was beyond the scope of the paper.

\section{References}

1. Alter, D. (2014). Facebook is looking to move into mobile payment. Money Morning, 14 April 2014, available at: www.moneymorning.com (accessed on 15 October 2016).

2. Anderson, E. W., \& Mittal, V. (2000). Strengthening the Satisfaction-Profit Chain. Journal of Service Research, 3(2), 107-112.

3. Ashley, C., \& Tuten, T. (2015). Creative strategies in social media marketing: An exploratory study of branded social content and consumer engagement. Psychology \& Marketing, 32(1), 15-27.

4. Bačík, R., \& Fedorko, R. (2014). Online advertising revenue - the current state of the domestic market. exclusive e-Journal, 6(4), 1-7.

5. Bačík, R., Fedorko, R., Kakalejčík, L., \& Pudło, R. (2015). The importance of Facebook ads in terms of online promotion. Journal of Applied Economic Sciences, (10)5, 131-138.

6. Belás, J., \& Kotásková, A. (2013). The satisfaction investigation of bank customers in Slovakia and Czech Republic. Biatec, 21(2), 1- 8.

7. Bernoff, J., \& Li, C. (2008). Harnessing the power of the oh-so-social web. MIT Sloan Management Review, 49(3), 36-42. 
8. Bianchi, C., \& Andrews, L. (2015). Investigating marketing managers' perspectives on social media in Chile. Journal of Business Research, 68(12), 2552-2559.

9. Canhoto, A. I., \& Clark, M. (2013). Customer service 140 characters at a time: The users' perspective. Journal of Marketing Management, 29(5/6), 522-544.

10. Chikandiwa, S. T., Contogiannis, E., \& Jembere, E. (2013). The adoption of social media marketing in South African banks. European Business Review, 25(4), 365-381.

11. Cooke, M., \& Buckley, N. (2008). Web 2.0, social networks and the future of market research. International Journal of Market Research, 50(2), 267-292.

12. Culnan, M. J., McHugh, P. J., \& Zubillaga, J. I. (2010). How large US companies can use twitter and other social media to gain business value. MIS Quarterly Executive, 9(4), 243-259.

13. Davis, F. D., Bagozzi, R. P., \& Warshaw, P. R. (1989). User acceptance of computer technology: a comparison of two theoretical models. Management Science, 35(8), 982-1003.

14. Dootson, P., Beatson, A., \& Drennan, J. (2016). Financial institutions using social media -do consumers perceive value?. International Journal of Bank Marketing, 34(1), 9-36.

15. Durkin, M., McGowan, P., \& Murray, L. (2014). Social media in small business-bank relationships. International Journal of Entrepreneurship and Innovation, 28(6), 251-264.

16. Durkin, M., Mulholland, G., \& McCartan, A. (2015). A socio-technical perspective on social media adoption: a case from retail banking. International Journal of Bank Marketing, 33(7), 944-962.

17. Ernst \& Young (2014). Winning through customer experience. EY Global Consumer Banking Survey 2014. Ernst and Young.

18. Farshid, M., Plangger, K., \& Nel, D. (2011). The social media faces of major global financial service brands. Journal of Financial Services Marketing, 16(3/4), 220-229.

19. Ferencová, M., Jeleňová, I., \& Kakalejčík, L. (2015). Social Media Usage in Product Information Searching. Applied Mechanics and Materials: IT Systems and Decisions in Business and Industry Practice, 795, 69-76.

20. Grabner-Kräuter, S., \& Faullant, R. (2008). Consumer Acceptance of Internet Banking: The Influence of Internet Trust. International Journal of Bank Marketing, 26(7), 483-504.

21. Greenberg, P. (2010). The impact of CRM 2.0 on consumer insight. The Journal of Business and Industrial Marketing, 25(6), 410-419.

22. Helkkula, A., \& Kelleher, C. (2010). Circularity of customer service experience and customer perceived value. Journal of Customer Behaviour, 9(1), 37-53.

23. Hennig-Thurau, T., Malthouse, E. C., Friege, C., Gensler, S., Lobschat, L., Rangaswamy, A., \& Skiera, B. (2010). The impact of new media on customer relationships. Journal of Service Research, 13(3), 311-133.

24. Kietzmann, J. H., Hermkens, H., McCarthy, I. P., \& Silvestre, B.S. (2011). Social media? Get serious! Understanding the functional building blocks of social media. Business Horizons, 54, 241-251.

25. Kim, J. H., \& Bae, Z. (2008). The role of online brand community in new product development: case studies on digital product manufacturers in Korea. International Journal if Innovation Management, 12(3), 357-376.

26. Lariviere, B., Joosten, H., Malthouse, E. C., van Birgelen, M., Aksoy, P., Kunz, W. H., \& Huang, M-H. (2013). The blending of consumer and firm value in the distinct context of mobile technologies and social media. Journal of Service Management, 24(3), 268-293.

27. Laroche, M., Habibi, M. R., Richard, M. O., \& Sankaranarayanan, R. (2012). The effects of social media based brand communities on brand community markers, value creation practices, brand trust and brand loyalty. Computers in Human Behavior, 28(5), 1755-1767.

28. Madche, A. (2015). Digitalization in Retail Banking: Differentiation and Standardization Through IT. Business and Information Systems Engineering, 57(1), 83-85. 
29. Medberg, G., \& Heinonen, K. (2014). Invisible value formation: a netnography in retail banking. International Journal of Bank Marketing, 32(6), 590-607.

30. Mitic, M., \& Kapoulas, A. (2012). Understanding the role of social media in bank marketing. Marketing Intelligence \& Planning, 30(7), 668-686.

31. Motwani, D., Shrimali, D., \& Agarwal, K. (2014). Customers' Attitude towards Social Media Marketing. Journal of Business Management \& Social Sciences Research, 3(4), 12-16.

32. Murray, L., Durkin, M., Worthington, S., \& Clark, V. (2014). On the potential for Twitter to add value in retail bank relationships. Journal of Financial Services Marketing, 19(4), 277-229.

33. Nielsen, J., \& Levy, J. (1994). Measuring Usability, Preference vs. Performance. Communications of the ACM, 37(4), 66-76.

34. Obar, J. A., \& Wildman, S. (2015). Social media definition and the governance challenge: An introduction to the special issue. Telecommunications policy, 39(9), 745-775.

35. Pikkarainen, T., Pikkarainen, K., Karjaluoto, H., \& Pahnila, S. (2004). Consumer acceptance of online banking: an extension of the technology acceptance model. Internet Research, 14(3), 224-235.

36. Porter, C. E., \& Donthu, N. (2006). Using the technology acceptance model to explain how attitudes determine Internet usage: The role of perceived access barriers and demographics. Journal of Business Research, 59, 999-1007.

37. Rainer, A., \& Puschmann, T. (2012). The rise of customer-oriented banking - electronic markets are paving the way for change in the financial services industry. Electronic Markets, 22(4), 203-215.

38. Rajaobelina, L., Brun, I., \& Toufaily, E. (2013). A relational classification of online financial institutioning consumers. International Journal of Financial institution Marketing, 31(3), 187-205.

39. Rokka, J., Karlsson, K., \& Tienari, J. (2014). Balancing acts: Managing employees and reputation in social media. Journal of Marketing Management, 30(7), 802-827.

40. Scarpi, D. (2010). Does size matter? An examination of small and large web-based brand communities. Journal of Interactive Marketing, 24(1), 14-21.

41. Schultz, D. E., \& Peltier, J. (2013). Social media's slippery slope: Challenges, opportunities and future research directions. Journal of Research in Interactive Marketing, 7(2), 86-99.

42. Schweidel, D. A., \& Moe, W.W. (2014). Listening in on social media: A joint model of sentiment and venue format choice. Journal of Marketing Research, 51(4), 387-402.

43. Spurrier, J. D. (2003). On the null distribution of the Kruskal-Wallis statistic. Journal of Nonparametric Statistics, 15(6), 685-691.

44. Statistical Office of the Slovak Republic (2016). Age Structure - SR, Areas, Regions, Districts, Urban, Rural. Available at: https://slovak.statistics.sk/wps/portal/ext/themes/demography/population/indicators

45. Stelzner, M. (2012). Social Media Marketing Industry Report. How marketers are using social Media to grow their business. Social Media Examiner.

46. Vejačka, M. (2012). Facebook advertising and its efficiency on the Slovak market. E+M Ekonomie a Management, 15(1), 116-127.

47. Vejačka, M. (2015). Consumer Acceptance of Contactless Payments in Slovakia. Journal of Applied Economic Sciences, 10(5), 760-767.

48. Vinerean, S., Cetina, I., Dumitrescu, L., \& Tichindelean, M. (2013). The Effects of Social Media Marketing on Online Consumer Behavior. International Journal of Business and Management, 14(8), 66-79.

49. Zabin, J. (2009). The ROI of Social Media Marketing: Why it pays to drive word of Mouth. San Carlos, CA: Aberdeen Group. 